\title{
Life Cycle Greenhouse Gas Emissions and Energy Analysis of Passive House with Variable Construction Materials
}

\author{
Silvia Bad'urová, Radoslav Ponechal, Pavol Ďurica \\ University of Žilina \\ Faculty of Civil Engineering, Department of Building Structures and Urban Planning \\ e-mail: silvia.badurova@uniza.sk, radoslav.ponechal@fstav.uniza.sk,pavol.durica@fstav.uniza.sk
}

\begin{abstract}
The term "passive house" refers to rigorous and voluntary standards for energy efficiency in a building, reducing its ecological footprint. There are many ways how to build a passive house successfully. These designs as well as construction techniques vary from ordinary timber constructions using packs of straw or constructions of clay. This paper aims to quantify environmental quality of external walls in a passive house, which are made of a timber frame, lightweight concrete blocks and sand-lime bricks in order to determine whether this constructional form provides improved environmental performance. Furthermore, this paper assesses potential benefit of energy savings at heating of houses in which their external walls are made of these three material alternatives. A twostorey residential passive house, with floorage of $170.6 \mathrm{~m}^{2}$, was evaluated. Some measurements of air and surface temperatures were done as a calibration etalon for a method of simulation.
\end{abstract}

Key words: passive house, sustainable development, simulation, thermal comfort

\section{Introduction}

Buildings are the largest greenhouse gas emission, representing $40 \%$ of nationwide $\mathrm{CO} 2$ emissions [1]. Because of the enormous environmental and economic impact of the building sector, there is a need to better understand the life cycle performance of buildings and to investigate methods for reducing their global warming potential (GWP). It is essential to consider the full life-cycle environmental performance of buildings, including the energy and resources required to construct, operate, and dispose of buildings over time. There are series of projects and methods to quantify the full life cycle carbon emissions of buildings around the world.

The research from the University of Melbourne quantify the embodied energy of modular prefabricated steel and timber multi-residential buildings in order to determine whether this form of construction provides improved environmental performance over conventional concrete construction methods [2]. They found that a steel structured prefabricated system resulted in reduced material consumption of up to $78 \%$ by mass compared to 
conventional concrete construction. However, the prefabricated steel building resulted in a significant increase ( $50 \%)$ in embodied energy compared to the concrete building. The study of Royal Institute of Technology Stockholm compares the life cycle impacts for two buildings - one wooden another - brick of identical physical dimensions for its entire life cycle period and attempts to find out which option is better from an environmental perspective [3]. The brick house has much more significant environmental impacts and the wood house is a better option under the name of environmental protection.

\section{Description of experimental passive house}

The wooden passive house was designed and built in the year 2011. It is situated in northern Slovakia (altitude $375.2 \mathrm{~m}$ a.s.1., outdoor winter design temperature $-15{ }^{\circ} \mathrm{C}$, average outdoor daytime temperature in summer $18.2^{\circ} \mathrm{C}$ ).

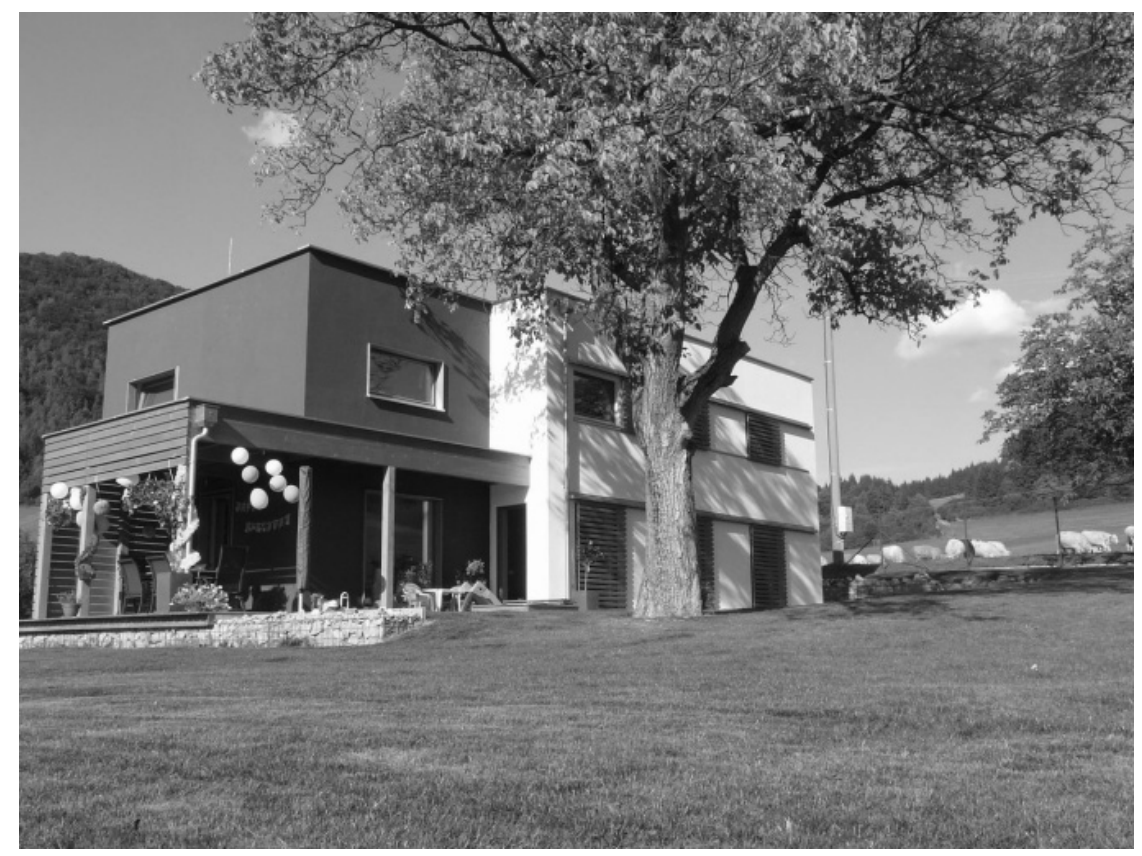

Figure 1: South-west view of wooden family house

It is a two-storey building of a simple constructional shape. Mainly nature materials were used for its construction. The composition of envelope constructions is shown in Fig. 2. Interior walls are made of timber frame constructions which are filled up with clay bricks. The building takes full advantage of solar heat gains. Wooden windows with triple-glazing $\left(\mathrm{U}_{\mathrm{W}}=0.79 \mathrm{~W} /\left(\mathrm{m}^{2} . \mathrm{K}\right)\right)$ are used for fillings. They are protected by outer shielding, which eliminates overheating of a building in summer. The part of southern and western facade is shielded by the roof construction of a terrace.

A heat pump, drawing heat from a geothermal source (air to water), provides for production, distribution and recuperation of heat. 


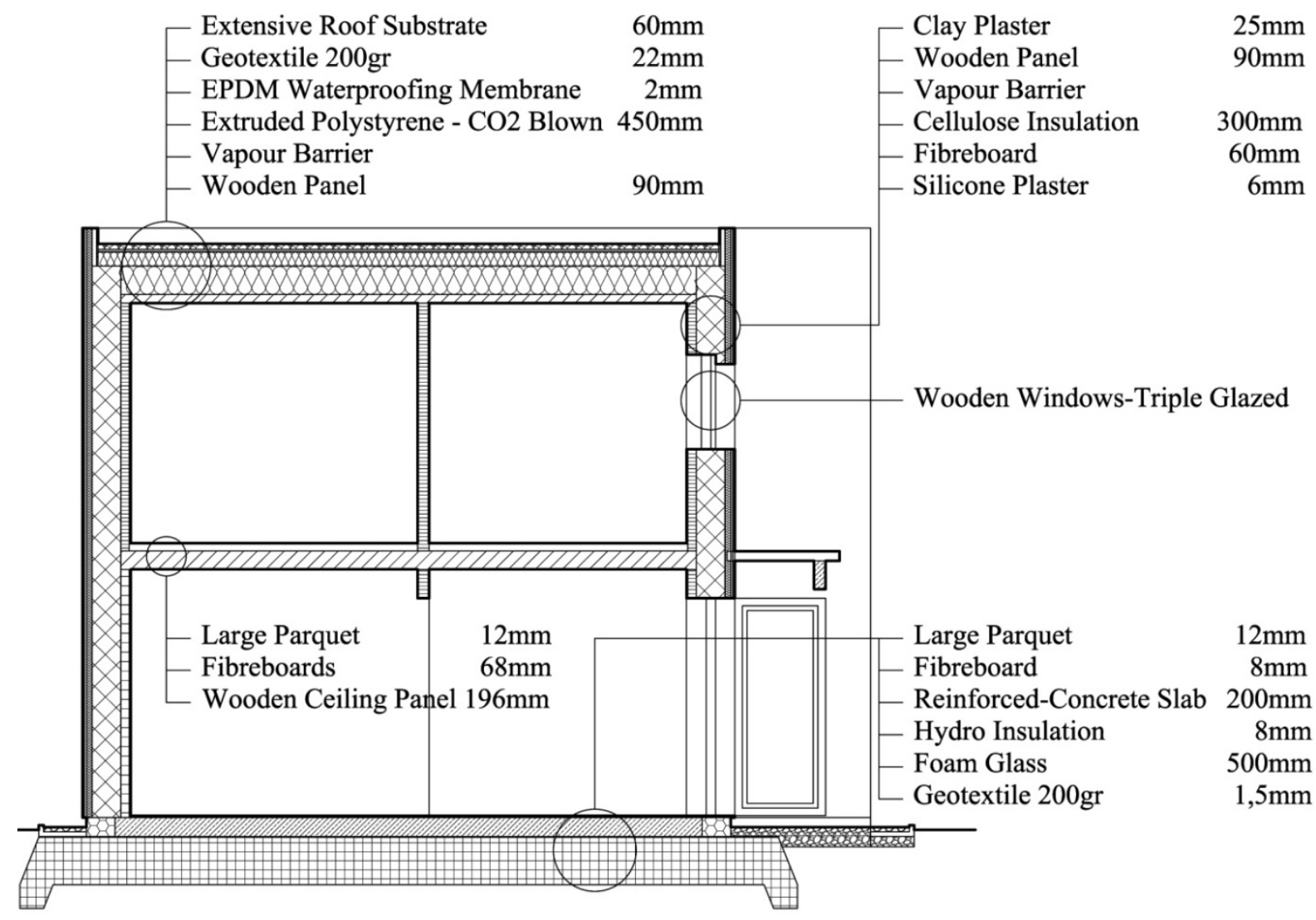

Figure 2: Simple section plan of the evaluated wooden house

\section{Evaluation of thermal performance and protection of building}

Envelope constructions and the family house as a whole was the subject of appraisal, as noted in STN 730540:2012 [4]. Thermal performance and protective computations demonstrated that all evaluated envelope constructions met the norm's requirements for stabilized temperature. The evaluation of the project's energy consumption indicates that this family house meets the relevant criteria of heat rate for heating, and can be classified as an energy efficient house - a passive building (see Tab. 1).

Table 1: Thermal energy characteristics under standardizes conditions in STN730540:2012

\begin{tabular}{|l|l|l|r|}
\hline Legend & Symbol & Units & Value \\
\hline Total Floor Area & $\mathrm{A}$ & {$\left[\mathrm{m}^{2}\right]$} & 225.66 \\
\hline Enclosed Volume & $\mathrm{V}$ & {$\left[\mathrm{m}^{3}\right]$} & 760.24 \\
\hline Shape Factor & $\mathrm{f}$ & {$[-]$} & 0.70 \\
\hline Average Heat Transfer Coefficient & $\mathrm{U}_{\mathrm{A}}$ & {$[1 / \mathrm{m}]$} & 0.14 \\
\hline Heat Use & $\mathrm{Q}_{\mathrm{h}}$ & {$\left[\mathrm{W} /\left(\mathrm{m}^{2} . \mathrm{K}\right)\right]$} & 3005.43 \\
\hline Energy Need for Heating & $\mathrm{E}_{2}$ & {$[\mathrm{kWh} / \mathrm{a}]$} & 13.32 \\
\hline Specific Energy Need for Heating - standardized & $\mathrm{E}_{2 \mathrm{~N}}$ & {$\left[\mathrm{kWh} /\left(\mathrm{m}^{2} . \mathrm{a}\right)\right]$} & 77.66 \\
\hline
\end{tabular}




\section{Comparison of the existing family house with alternative envelopes}

According to project data, three alternative designs of a family house were created. Vertical and horizontal constructions in the original design were changed. The outer dimensions of a building, the way of founding, surface working and a technical solution were preserved.

All of exterior envelope structures are also designed in such a way that it could be possible to achieve the same heat transfer coefficient as in original structures.

The $\mathrm{B}$ version is a pillar construction with a wooden cassette ceiling, the $\mathrm{C}$ version is a sandlime wall with a reinforced concrete ceiling, and the $\mathrm{D}$ version is a porous concrete construction [6]. For the material structures see Fig. 3 to 5.

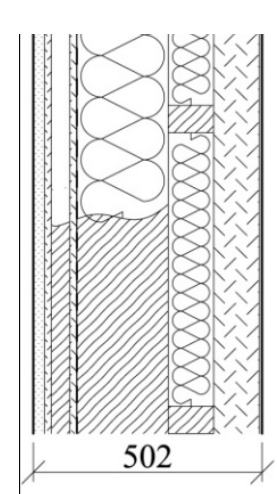

- Clay Plaster

- Fibreboard

- Enclosed Air Space (Timber Frame)

- OSB Board

- Vapour Barrier

- Sheep Wool Insulation (Wooden Grid)

- Fireboard

- Silicone Plaster

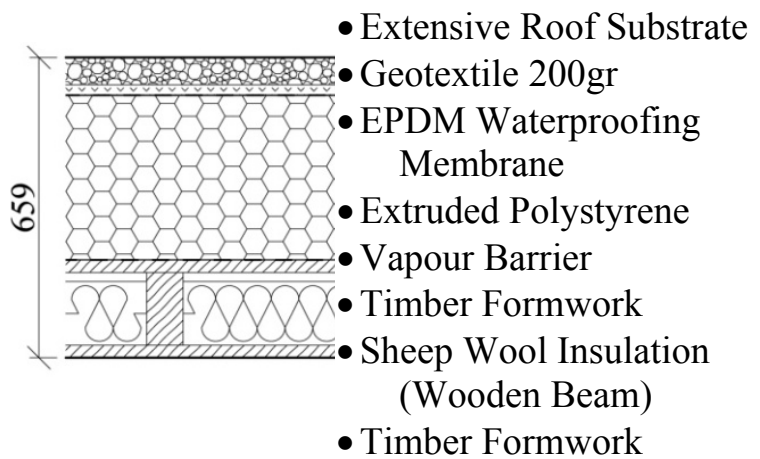

Figure 3: Wall and roof material construction for version B

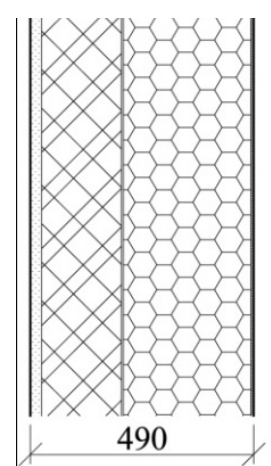

- Clay Plaster

- Lime-sand Block

- Adhesive Mortar

- Expanded Polystyrene

- Silicone Plaster

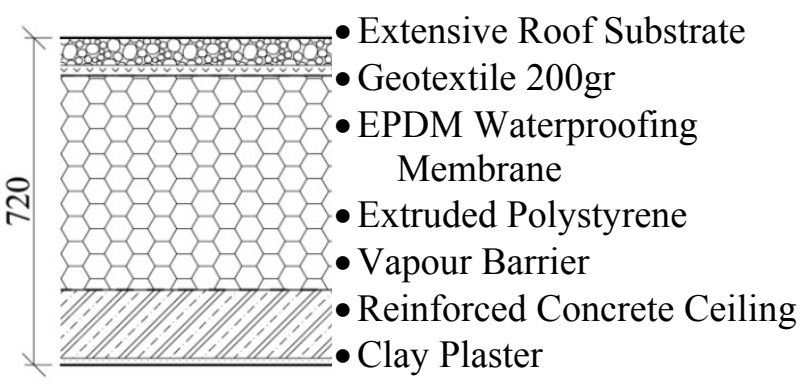

Figure 4: Wall and roof material construction for version $\mathrm{C}$

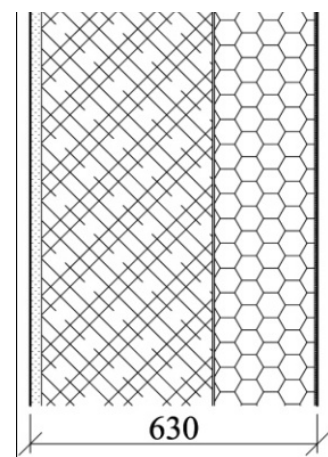

- Clay Plaster

- Porous Concrete Block

- Adhesive Mortar

- Expanded Polystyrene

- Silicone Plaster

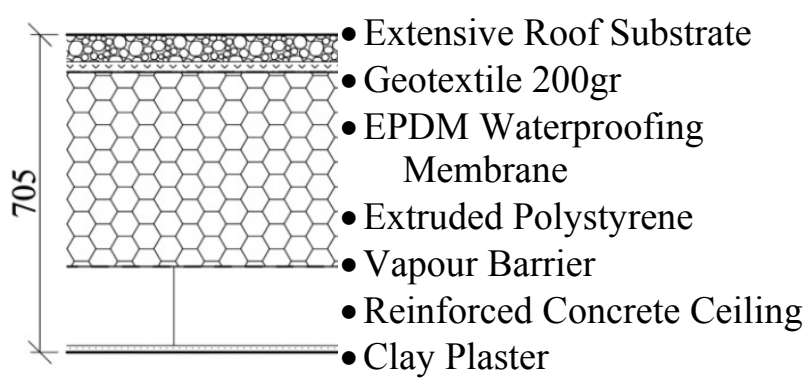

Figure 5: Wall and roof material construction for version D 


\section{$5 \quad$ Energy performance of experimental building}

One of the main criterions in design of a passive house is the requirement that the building must not use more than $15 \mathrm{kWh} /\left(\mathrm{m}^{2} . \mathrm{a}\right)$ in heating and cooling energy and the total primary energy (source energy for electricity and etc.) consumption (primary energy for heating, hot water and electricity) must not be more than $120 \mathrm{kWh} /\left(\mathrm{m}^{2}\right.$.a). The specific heat load for the heating source at design temperature is recommended, but not required, to be less than $10 \mathrm{~W} / \mathrm{m}^{2}$. In warmer climates and/or during summer months, excessive temperatures may not occur more than $10 \%$ of the time. The building must not leak more air than 0.6 times the house volume per hour $\left(\mathrm{n}_{50} \leq 0.6(1 / \mathrm{h})\right)$ at $50 \mathrm{~Pa}\left(\mathrm{~N} / \mathrm{m}^{2}\right)$ as tested by a Blower door.

The air tightness test with the result $\mathrm{n}_{50}=0.14(1 / \mathrm{h})$ was made during constructional works. This test was repeated in giving the building for usage and its resulting value was $n_{50}=0.21$ $(1 / \mathrm{h})$. Since the value $\mathrm{n}_{50}$ can be obtained only in direct measuring in situ, it is considered with the value $\mathrm{n}_{50}=0.6(1 / \mathrm{h})$ in computations.

The program PHPP (Passive House Planning Package) was used for computations of energy performance of buildings. The results are shown in Tab. 2.

Table 2: The results of energy performance in comparison with alternatives

\begin{tabular}{|l|l|r|r|r|r|}
\hline Legend & \multirow{2}{*}{ Units } & \multicolumn{4}{|c|}{ Version } \\
\cline { 3 - 6 } & & \multicolumn{1}{c|}{ A } & \multicolumn{1}{c|}{ B } & \multicolumn{1}{c|}{ D } \\
\hline Treated Floor & {$\left[\mathrm{m}^{2}\right]$} & 166.16 & 164.16 & 165.44 & 154.24 \\
\hline Specific Space Heat Demand & {$\left[\mathrm{kWh} /\left(\mathrm{m}^{2} \mathrm{a}\right)\right]$} & 14.86 & 15.25 & 14.63 & 15.82 \\
\hline Specific Primary Energy Demand & {$\left[\mathrm{kWh} /\left(\mathrm{m}^{2} \mathrm{a}\right)\right]$} & 71.93 & 72.99 & 71.73 & 76.86 \\
\hline Heating Loss & {$\left[\mathrm{W} / \mathrm{m}^{2}\right]$} & 15.72 & 15.73 & 15.81 & 16.65 \\
\hline Frequency of Overheating $\left(\geq 25^{\circ} \mathrm{C}\right)$ & {$[\%]$} & 2.12 & 2.61 & 0.58 & 2.31 \\
\hline Heating Load & {$\left[\mathrm{W} / \mathrm{m}^{2}\right]$} & 5.63 & 5.68 & 5.61 & 5.87 \\
\hline
\end{tabular}

Results of evaluation indicate that $\mathrm{A}, \mathrm{B}$ and $\mathrm{C}$ versions meet requirements of a passive house, while results of the $\mathrm{D}$ version are by $6 \%$ worse than other buildings.

\section{Experimental Measurement in the Winter Season}

The measurement of physical environment parameters was undertaken in the family house under operating conditions as noted in STN 730550 [5]. Measurements were made from 4th February 2012 to 18 th March 2012.

The temperature and relative humidity of internal air was monitored in selected rooms, as well as an external air temperature and the internal surface temperature of selected constructions, in half-hour intervals. External air temperatures during measurements fluctuated from $-19.8{ }^{\circ} \mathrm{C}$ to $19.5{ }^{\circ} \mathrm{C}$, with the average outdoor temperature below zero $\left(\theta_{\text {ae,av }}=-1.3{ }^{\circ} \mathrm{C}\right)$. The temperature of internal air fluctuated from $30.4{ }^{\circ} \mathrm{C}$ (the bathroom on the first floor) to $20.1{ }^{\circ} \mathrm{C}$ (the children room on the second floor). Average indoor air temperature is $\theta_{\text {ai,av }}=22.4{ }^{\circ} \mathrm{C}$. 
Internal relative humidity was observed in the kitchen. It is fluctuated from $25.3 \%$ to $63.7 \%$ (averaging $36.7 \%$ ). Considering the thermal/humidity microclimate, suitable parameters of heating comfort in the neutral zone were achieved.

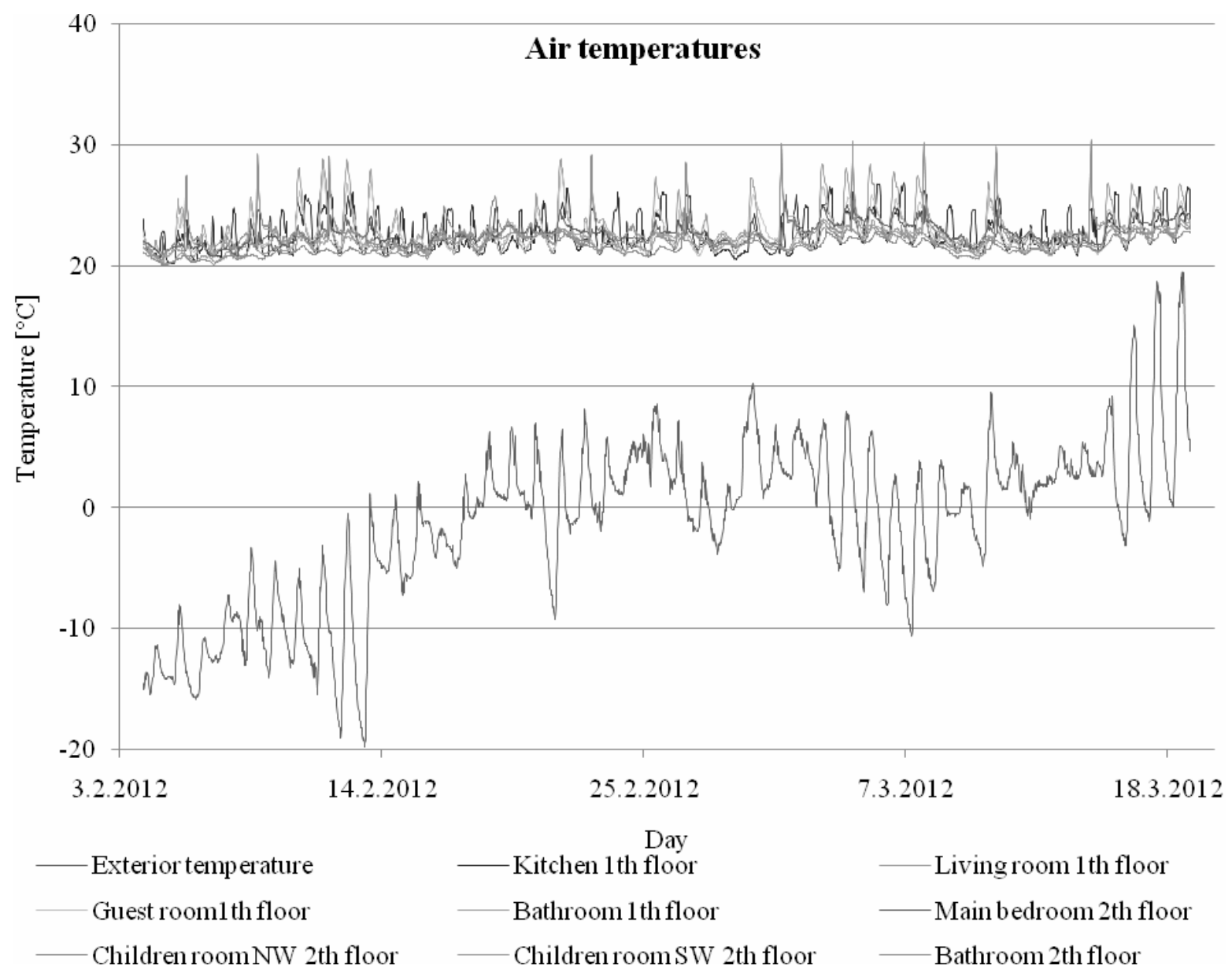

Graph 1: Real air temperatures (from 4.2.2012 to 18.3.2012)

\section{Energy simulation of buildings}

Numerical simulation calculations were made with EnergyPlus simulation program. The heating loads, the energy annually delivered for heating and maximum dry bulb interior temperatures are evaluated in 13 zones of a model with solar obstacles (see Fig. 6).

For the sake of simplification of the heating load calculation, it was considered 24 hour operation of the system without day or night interruption. The sensor of dry bulb air temperature was set at $20^{\circ} \mathrm{C}$ for each room. Fully convective heating was simulated in this study. The predicted heating loads and delivery of energy is strongly dependant on surface convective heat transfer coefficient of used model. The variations $10 \%$ to $15 \%$ are 
commonly allowed. Standard International Weather for the Energy Calculation climate file for the Ostrava city was used in this study.

The heating load and annual calculations were done with casual heat gains $2.1 \mathrm{~W} / \mathrm{m}^{2}$. The uniform air exchange number $\mathrm{n}=0.5(1 / \mathrm{h})$ and $20{ }^{\circ} \mathrm{C}$ supply air temperature was used for each room. The ventilating system with recuperation was supposed to have $80 \%$ effectivity.

Real operating conditions were used for the calibration calculation, where the following data were measured: internal shading of blinds, air tightness $n_{50}=0.21(1 / \mathrm{h})$. The external shading blinds (set point at $23^{\circ} \mathrm{C}$ of mean air temperature) and air tightness $n_{50}=0.6(1 / \mathrm{h})$, was used for comparative test calculation of construction variants (Tab. 3).

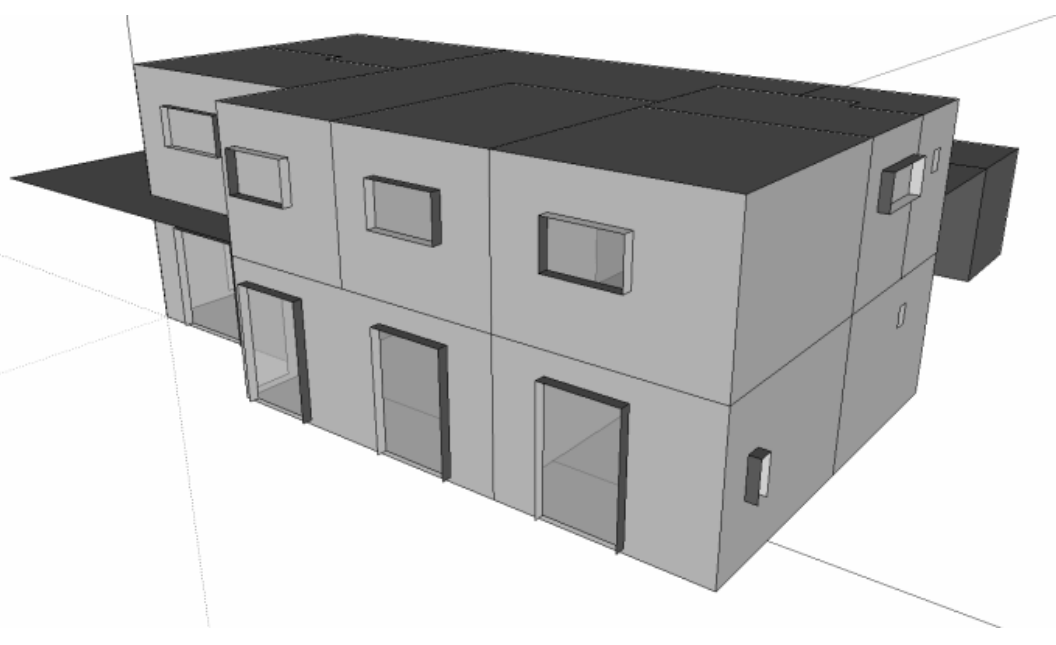

Figure 6: The simplified simulation model with solar obstacles

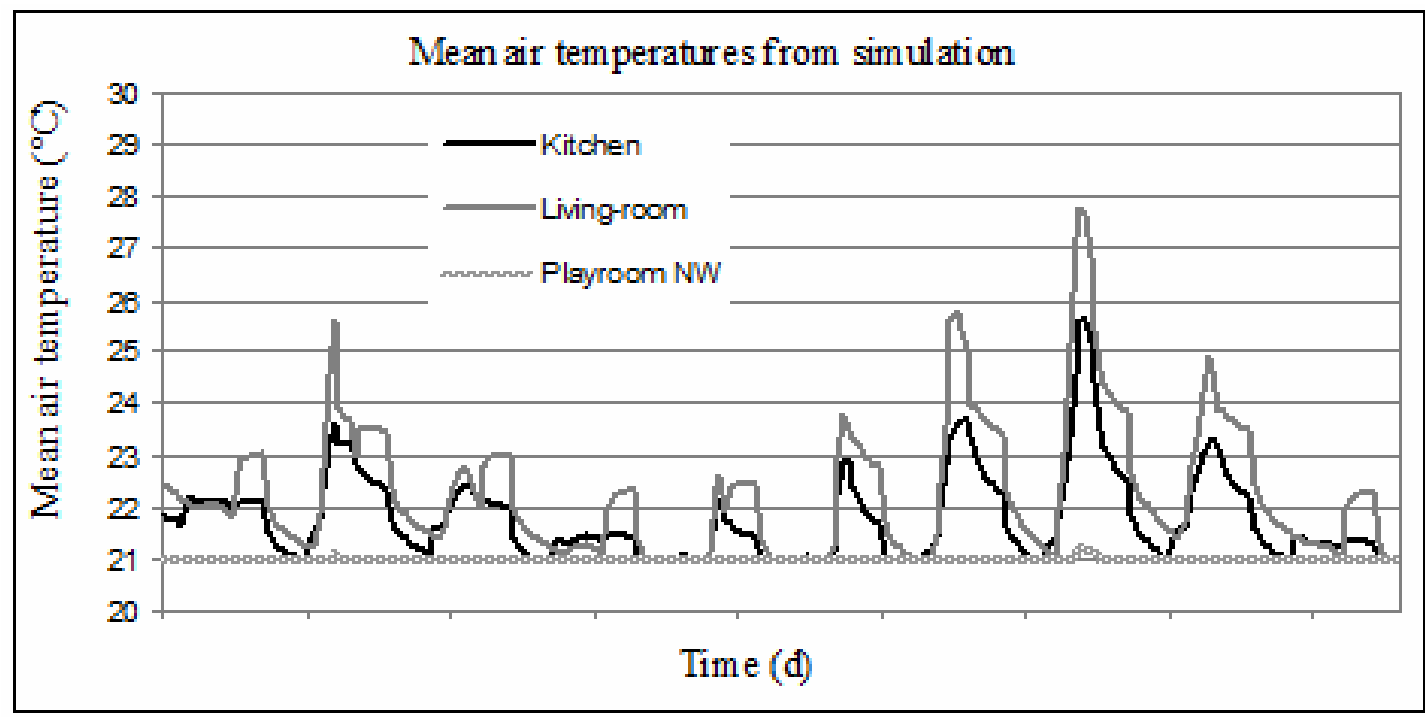

Graph 2: Mean air temperatures from simulation in winter season 


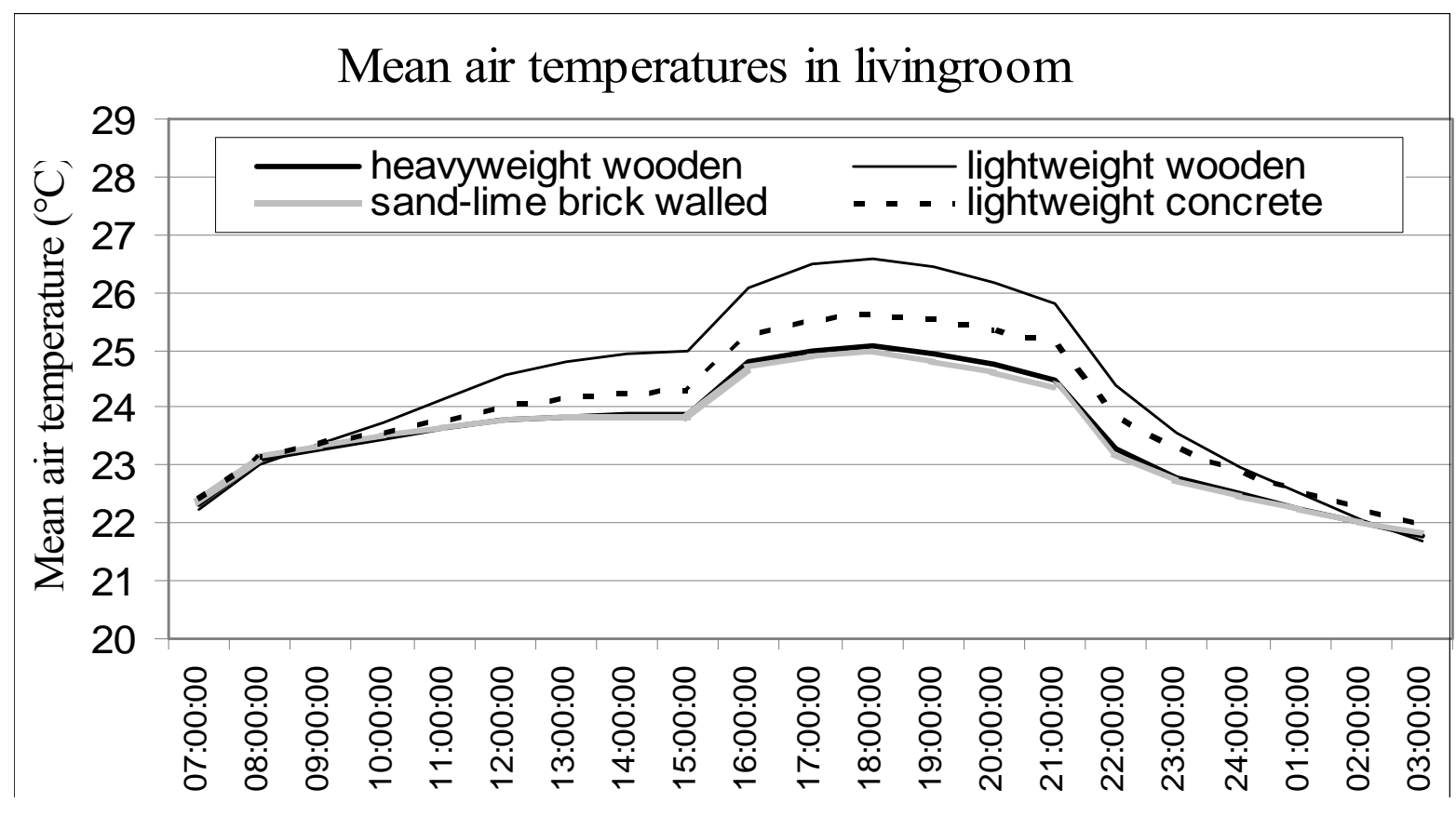

Graph 3: Mean air temperatures in the living room - summer hot day

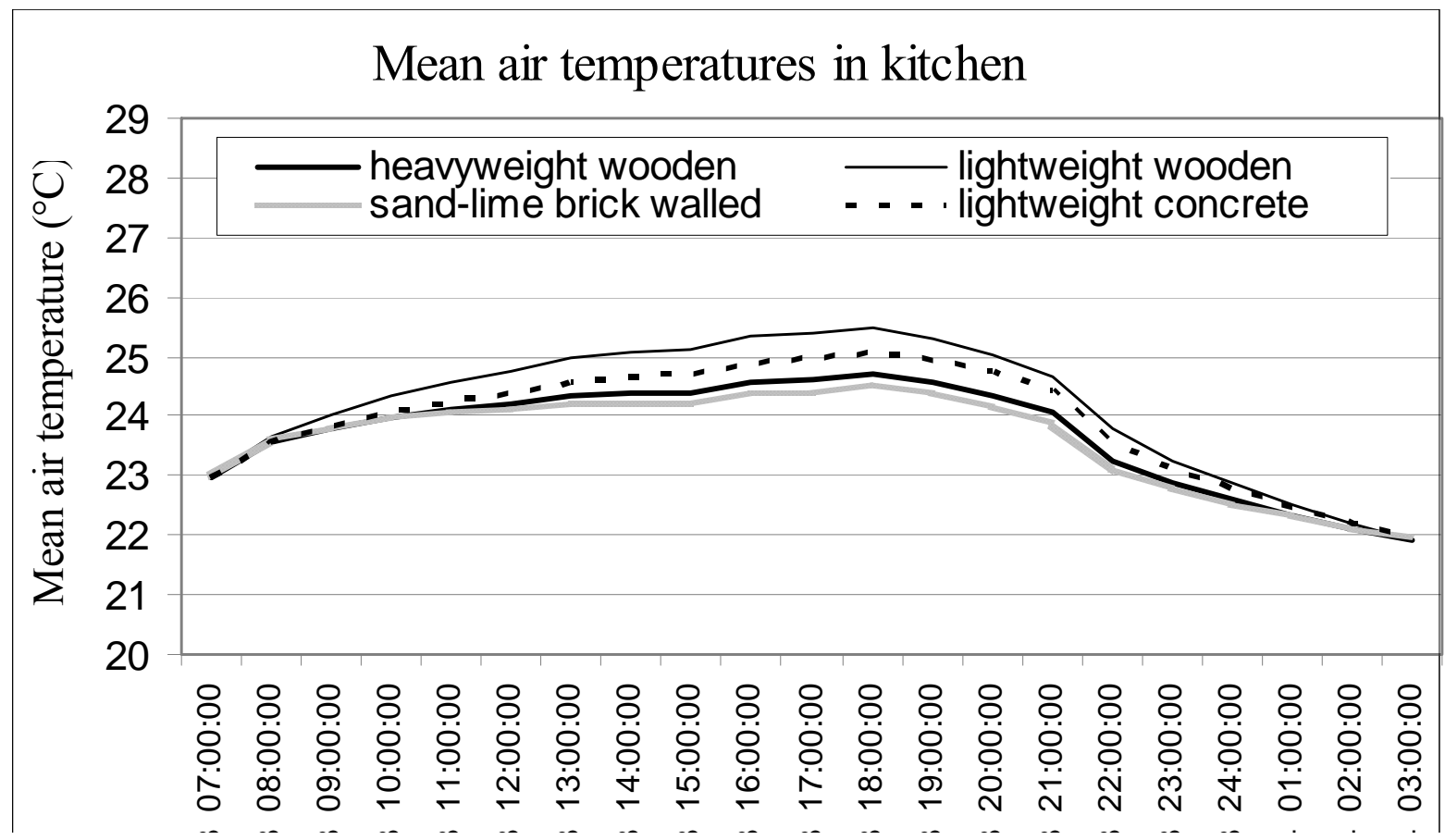

Graph 4: Mean air temperatures in the kitchen - summer hot day 


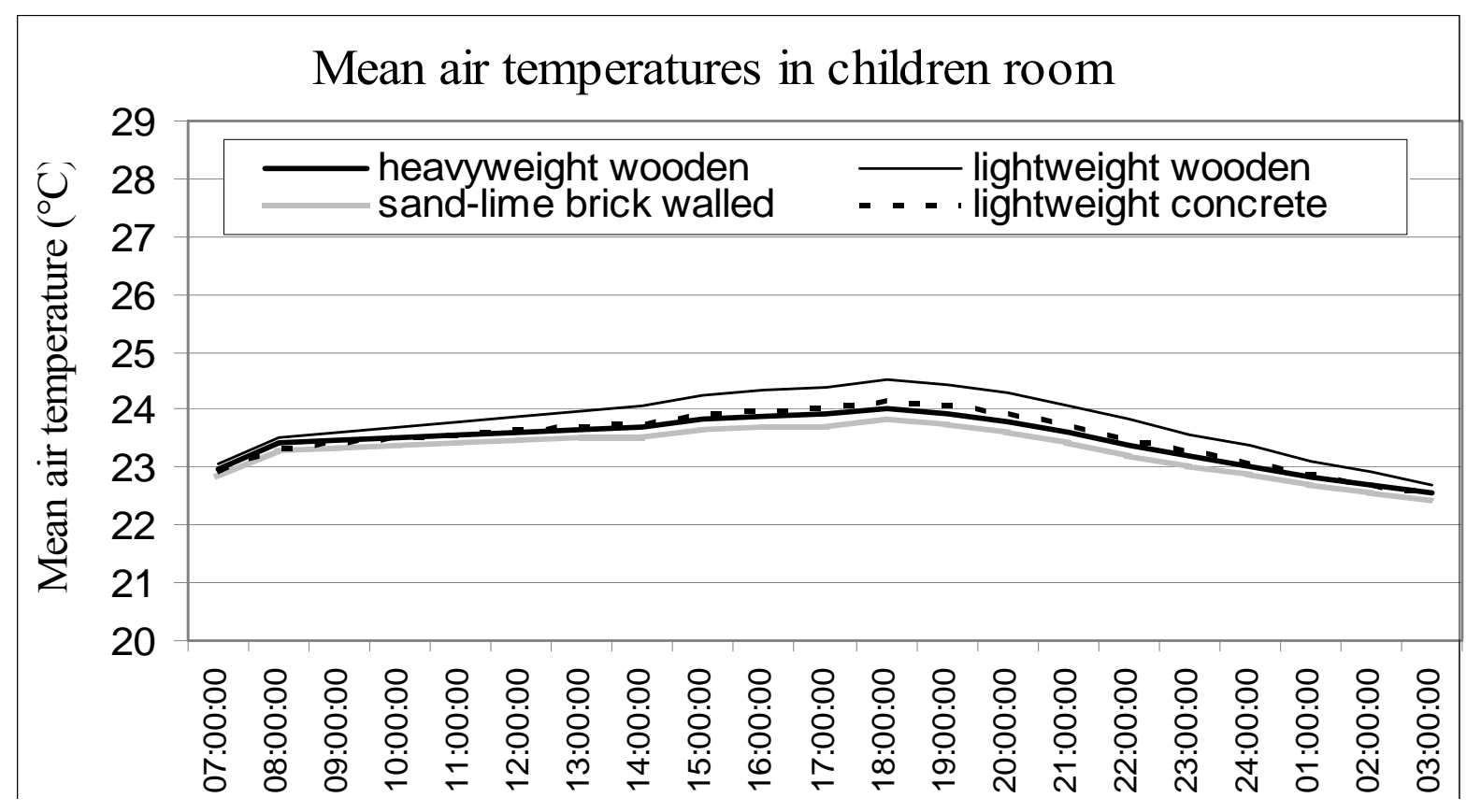

Graph 5: Mean air temperatures in the children room - summer hot day

Table 3: Results from a simulation model in comparison with alternatives

\begin{tabular}{|l|l|r|r|r|r|}
\hline \multirow{2}{*}{ Legend } & \multirow{2}{*}{ Units } & \multicolumn{4}{|c|}{ Version } \\
\cline { 3 - 6 } & & \multicolumn{1}{|c|}{ A } & \multicolumn{1}{c|}{ B } & \multicolumn{1}{c|}{ D } \\
\hline \multirow{2}{*}{ Annual Heating Demand } & {$[\mathrm{kWh} / \mathrm{a}]$} & 1656 & 1975 & 1664 & 1872 \\
\cline { 2 - 6 } & {$\left[\mathrm{kWh} / \mathrm{m}^{2}\right]$} & 9.87 & 11.78 & 9.92 & 11.16 \\
\hline Mean Air Temperature max. (1) & {$\left[{ }^{\circ} \mathrm{C}\right]$} & 26.0 & 27.8 & 25.8 & 26.7 \\
\hline Occurrence of Overheating (2) & {$[\mathrm{hr} / \mathrm{a}]$} & 32.2 & 345.2 & 36.5 & 128.7 \\
\cline { 2 - 6 } & {$[\%]$} & 0.4 & 3.9 & 0.4 & 1.5 \\
\hline
\end{tabular}

(1) Mean air temperature in the living room

(2) Annual occurrence of mean air temperature in the living room over $25\left[{ }^{\circ} \mathrm{C}\right]$

The result of simulation shows that the original construction - the A version - is the most advantageous.

\section{Environmental Assessment of Buildings}

Environmental appraisal for each construction is compared to the indicator $\mathrm{OI} 3_{\mathrm{KON}}$. A structure's $\mathrm{OI}_{\mathrm{KON}}$ as an environmental indicator (for $1 \mathrm{~m}^{2}$ of a structure) encompasses $\mathrm{OI}_{\mathrm{PECnr}}$ (environmental indicator of non-renewable primary energy content, $\mathrm{PECn.r.}$.), $\mathrm{OI}_{\mathrm{GWP}}$ (environmental indicator of global warming potential GWP), and $\mathrm{OI}_{\mathrm{AP}}$ (environmental indicator of acidification potential AP), in proportions of one-third each. This is calculated as shown below: 


$$
O I 3_{K O N}=1 / 3 O I_{P E C n r}+1 / 3 O I_{G W P}+1 / 3 O I_{A P} \quad\left[P t s / m^{2}\right]
$$

The buildings are made up of a multitude of different structures. One of the possibilities how to determine environmental potential of whole building is using indicator $\mathrm{OI} 3_{\mathrm{BGX}}$. A indicator $\mathrm{OI} 3_{\mathrm{BGX}}$ is the area-weighted mean of the $\mathrm{OI} 3_{\mathrm{KON}}$ values of all the structures contained within the envelope boundary [7].

$$
O I 3_{\mathrm{BGX}}=\frac{\sum_{i=1}^{N} A_{i} \cdot O I 3_{K O N}}{\sum_{i=1}^{N} A_{i}}
$$

The calculation includes all materials permanently installed in the house. The calculation does not take account of technical installations, transport and material manipulation in the site.

\begin{tabular}{|c|c|c|c|c|c|c|}
\hline \multirow[t]{2}{*}{ Legend } & \multirow[t]{2}{*}{ Symbol } & \multirow[t]{2}{*}{ Units } & \multicolumn{4}{|c|}{ Version } \\
\hline & & & $\mathrm{A}$ & B & $\mathrm{C}$ & $\mathrm{D}$ \\
\hline Total Weight & $\mathrm{m}$ & {$\left[\mathrm{kg} / \mathrm{m}^{2}\right]$} & 124.74 & 130.80 & 334.87 & 264.73 \\
\hline $\begin{array}{l}\text { Potential Environmental } \\
\text { Impact }\end{array}$ & PEI & {$\left[\mathrm{MJ} / \mathrm{m}^{2}\right]$} & 572.24 & 851.56 & 925.75 & 1350.58 \\
\hline $\begin{array}{l}\text { Global Warming Potential } \\
\mathrm{CO}_{2, \text { eqv }}\end{array}$ & GWP & {$\left[\mathrm{kg} / \mathrm{m}^{2}\right]$} & 24.43 & 43.11 & 56.99 & 91.65 \\
\hline $\begin{array}{l}\text { Acidification Potential } \\
\mathrm{SO}_{2, \text { eqv }}\end{array}$ & AP & {$\left[\mathrm{kg} / \mathrm{m}^{2}\right]$} & 0.25 & 0.33 & 0.18 & 0.26 \\
\hline Environmental indicator & $\mathrm{OI} 3_{\mathrm{KON}}$ & {$\left[\mathrm{Pts} / \mathrm{m}^{2}\right]$} & 20 & 43 & 29 & 60 \\
\hline
\end{tabular}

Table 4: Results of environmental potentials in comparison with alternatives for $1 \mathrm{~m}^{2}$ of a wall

Table 5: Results of environmental potentials in comparison with alternatives for $1 \mathrm{~m}^{2}$ of a roof

\begin{tabular}{|l|l|l|r|r|r|r|}
\hline \multirow{2}{*}{ Legend } & \multirow{2}{*}{ Symbol } & \multirow{2}{*}{ Units } & \multicolumn{5}{|c|}{ Version } \\
\cline { 4 - 7 } & & & $\mathrm{A}$ & \multicolumn{1}{c|}{$\mathrm{B}$} & \multicolumn{1}{c|}{$\mathrm{C}$} & \multicolumn{1}{c|}{$\mathrm{D}$} \\
\hline Total Weight & $\mathrm{m}$ & {$\left[\mathrm{kg} / \mathrm{m}^{2}\right]$} & 53.84 & 56.11 & 412.72 & 124.62 \\
\hline $\begin{array}{l}\text { Potential Environmental } \\
\text { Impact }\end{array}$ & $\mathrm{PEI}$ & {$\left[\mathrm{MJ} / \mathrm{m}^{2}\right]$} & 1177.66 & 1351.21 & 1568.99 & 1315.89 \\
\hline $\begin{array}{l}\text { Global Warming Potential } \\
\mathrm{CO}_{2, \mathrm{eqv}}\end{array}$ & $\mathrm{GWP}$ & {$\left[\mathrm{kg} / \mathrm{m}^{2}\right]$} & 41.39 & 62.34 & 82.74 & 61.69 \\
\hline $\begin{array}{l}\text { Acidification Potential } \\
\mathrm{SO}_{2, \text { eqv }}\end{array}$ & $\mathrm{AP}$ & {$\left[\mathrm{kg} / \mathrm{m}^{2}\right]$} & 0.27 & 0.31 & 0.37 & 0.29 \\
\hline Environmental indicator & $\mathrm{OI} 3_{\mathrm{KON}}$ & {$\left[\mathrm{Pts} / \mathrm{m}^{2}\right]$} & 46 & 61 & 80 & 56 \\
\hline
\end{tabular}

The environmental quality of conventional structures is shown by the environmental indicator $\mathrm{OI} 3_{\mathrm{KON}}$ on a scale of 0 to 100 points. For example, an outside wall with an $\mathrm{OI} 3_{\mathrm{KON}}$ of 70 is typical of a standard structure without any environmental optimizations; an $\mathrm{OI} 3_{\mathrm{KON}}$ of 15 or 
less can only be attained by means of environmental optimization or by a very light structural design [7].

Table 6: Results of environmental potentials in comparison with alternatives for whole house

\begin{tabular}{|c|c|c|c|c|c|c|}
\hline \multirow{2}{*}{ Legend } & \multirow{2}{*}{ Symbol } & \multirow{2}{*}{ Units } & \multicolumn{4}{|c|}{ Version } \\
\hline & & & A & B & C & D \\
\hline \multirow[t]{2}{*}{ Walls } & $\mathrm{A}_{1}$ & {$\left[\mathrm{~m}^{2}\right]$} & \multicolumn{4}{|c|}{269.97} \\
\hline & $\mathrm{OI} 3_{\mathrm{KON}, 1}$ & {$\left[\mathrm{Pts} / \mathrm{m}^{2}\right]$} & 20 & 43 & 29 & 60 \\
\hline \multirow[t]{2}{*}{ Roof } & $\mathrm{A}_{2}$ & {$\left[\mathrm{~m}^{2}\right]$} & \multicolumn{4}{|c|}{112.83} \\
\hline & $\mathrm{OI} 3_{\mathrm{KON}, 2}$ & {$\left[\mathrm{Pts} / \mathrm{m}^{2}\right]$} & 46 & 61 & 80 & 56 \\
\hline \multirow[t]{2}{*}{ Floor } & $\mathrm{A}_{3}$ & {$\left[\mathrm{~m}^{2}\right]$} & \multicolumn{4}{|c|}{112.83} \\
\hline & $\mathrm{OI} 3_{\mathrm{KON}, 3}$ & {$\left[\mathrm{Pts} / \mathrm{m}^{2}\right]$} & 89 & 89 & 89 & 89 \\
\hline \multirow[t]{2}{*}{ Windows } & $\mathrm{A}_{4}$ & {$\left[\mathrm{~m}^{2}\right]$} & \multicolumn{4}{|c|}{34.03} \\
\hline & $\mathrm{OI} 3_{\mathrm{KON}, 4}$ & {$\left[\mathrm{Pts} / \mathrm{m}^{2}\right]$} & 32 & 32 & 32 & 32 \\
\hline \multirow[t]{2}{*}{ Door } & $\mathrm{A}_{5}$ & {$\left[\mathrm{~m}^{2}\right]$} & \multicolumn{4}{|c|}{2.1} \\
\hline & $\mathrm{OI} 3_{\mathrm{KON}, 5}$ & {$\left[\mathrm{Pts} / \mathrm{m}^{2}\right]$} & 29 & 29 & 29 & 29 \\
\hline Environmental indicator & $\mathrm{OI} 3_{\mathrm{BGX}}$ & [Pts] & 39 & 56 & 53 & 63 \\
\hline
\end{tabular}

The results indicate that Version A (heavy weight wooden) is the preferable solution with the lowest impacts for most categories, whereas the alternatives with higher impacts are Version $\mathrm{D}$ (porous concrete block masonry).

\section{Summary}

The construction and operation of buildings is one of the largest consumers of material and energy resources and polluters of environment. An ecological construction is a reaction to the current condition of environment. The solution that provides an ecological construction, operation, and demolition, as well as comfortable living, is the building with low energy consumption or passive buildings based on wood.

Low heating requirements of $15 \mathrm{kWh} /\left(\mathrm{m}^{2} . \mathrm{a}\right)$ are regarded as an excellent, as well as values of environmental indicator for buildings or structures with fewer than 15 OI3 points.

The presented theoretical ratings and experimental measurements demonstrate that the right choice of construction materials, an architectural construction, architectural environment and operational practice can prevent negative effects on environment which can occur as early as in the phase of building design. The goal of environmental evaluation systems is a design, construction and operation of buildings with minimal environmental risks for users and with minimal negative impact on environment.

\section{References}

[1] www.iea.org

[2] Lu Aye, et al. (2012). Life cycle greenhouse gas emissions and energy analysis of prefabricated reusable building modules. Energy and Buildings. 47. pp. 159-168. 
[3] http://www.infra.kth.se/fms/utbildning/lca/project\%20reports/Group\%206\%20-\%20House.pdf

[4] STN 730540 (2002). Thermal performance of buildings and components. Thermal protection of building. Slovak Standards Institute, Bratislava.

[5] STN 730550 (1998). Measuring of heating energy consumption. In situ method. Slovak Standards Institute, Bratislava.

[6] Vertal', M. (2011). Determination of material parameters of selected types of porous concrete for the purposes of numerical analysis of moisture performance of building structures in the region of Slovakia - moisture storage function. SSP - Journal of Civil Engineering. Vol.6, Issue 1, pp. 97-105.

[7] I B O (2011). Guidelines to calculating the OI3 indicators Version 2.2. Österreichisches Institut für Bauen und Ökologie GmbH. 